\title{
RE-IMAGINING HISTORIES, RE-INVENTING THE SELF IN IAN MCEWAN'S ATONEMENT
}

\author{
Vanja Vukićević Garić, University of Montenegro, vanjav@t-com.me \\ 10.31902/fll.26.2019.14 \\ UDK 821.111-31.09
}

\begin{abstract}
Justifiably classified as an example of postmodern realism, or a "restorative metafiction" (O'Hara), Ian McEwan's popular and critically acclaimed novel Atonement (2001) in its entirety reasserts its author's frequently cited statement that "imagining what it is like to be someone other than yourself is at the core of our humanity." Focusing mainly on the metafictional ending, which, as a kind of unusual post-scriptum, introduces a thematic, structural and an ontological twist re-directing the whole story, this paper explores the limits and the power of creative imagination to re-generate, amend and meaningfully extend personal histories, pointing to the fundamentally ethical dimension of the contemporary self-conscious fiction. The phenomenological connection between ars memoria, imagining, (re-)writing and the Self is seen through the main assumption of the existential psychology that the subject is capable of transcending oneself, recreating and re-inventing oneself in and by means of narrating the self as well as others. Analysing Briony Tallis as both a character and an author within the novel, in her narrative of her own as well as others' histories, this paper will address ethical possibilities of the self-reflective fiction to connect subjectivity to the world questioning at the same time the boundaries of past, present and the idea of reality.
\end{abstract}

Keywords: postmodern realism, re-imagining, story-telling, Self, acceptance, enlargement, narrative ethics.

The metafictional, self-reflexive component of Ian McEwan's Atonement (2001), explicitly foregrounded in the final chapter but, in fact, implicitly present all along in the subtle layering of themes and in the narrative structure, ${ }^{1}$ has been both highly praised by the reviewers and criticized as an example of frustrating and self-indulgent postmodernist fashion that needlessly interferes in and disrupts what could be a successful example of psychological and social realism in the contemporary novel. The purpose of this article is to examine precisely the psychological, social and ethical dimension of self-referential fiction, which in McEwan's case does not work against realist referentiality and

1 Finney's in-depth explanation of the specific and all-pervading self-consciousness of Atonement focuses on various narrative elements present from the beginning of the novel, such as: literary allusions and deliberate intertextuality, conspicuous modulations of styles, narrative anticipations, the role which literature plays in the lives of characters, etc. Cf. Brian Finney, "Briony's Stand Against Oblivion: The Making of Fiction in lan McEwan's Atonement." 
mimesis, but, more importantly, works together with them, in order to point towards the restorative and transformative potential of connecting fiction and reality, imagination and responsibility, memory and creativity. Contemporary tendencies in the British novel have largely reflected a renewed interest in history and historical imagination, but, as many critics and novelists have observed, in a way that significantly surpasses deconstructionist experiment of historiographic metafiction, combining, in fact, postmodernist (self)awareness with more traditional forms of storytelling. Ian McEwan is one of the most prominent contemporary authors in whose work, particularly in his later fiction, this "crossroads" situation, to use Lodge's phrase, ${ }^{2}$ has been most appealingly resolved. The closed realm of the private and psychological, characteristic of his early stories and novels, has been widened to include public, social and national histories, along with increasingly more self-conscious narrative modes which, nevertheless, brought in also new narrative conscience - the one rarely found in the "purely" postmodernist, highly self-referential, or anti-referential, playfulness. Exemplary in this as well as in many other respects, and critically often appraised as possibly his best novel, Atonement can be said to belong to what David O'Hara called "an unusual brand of self-conscious narrative", and "a restorative metafiction" (O'Hara), which is a rare brand precisely because of its ethical implications. It is a combination of postmodernism and realism (often called postmodern realism or realist postmodernism) in its tendency to restore and reaffirm, at fictional and metafictional level, mimetic claims and the ethical relationship between author, text and readers, neglected and obliterated in the postmodernist fiction. As O'Hara further explains, "storytelling does not mark the beginning of a free-play of signifiers or a dispersal of constituting fictions, but rather the beginning of a dialogical and ethical relationship between texts and readers; of stories not just being told from one to another, but by one for another" (O'Hara, emphasis in original). Atonement, as we shall see in the metafictional twist of its last chapter, establishes this kind of telos: it self-reflexively demonstrates that it has been written to make up for the mistake inflicted on the others; it is for another that it has been produced, through writing and rewriting, imagining and re-imagining, remembering and recalling, and - most importantly - through projecting oneself into another, by means of which the Self is (re)constituted and extended in a meaningful and ethical way. It is a novel about the limits and powers that fiction can have in human life; a story about the great responsibilities and risks, as well as enormous existential potentials of storytelling to shape, change and amplify our experience of time and reality, our identity and its positioning in the world.

2 Cf. David Lodge, The Novelist at the Crossroads: And Other Essays on Fiction and Criticism. 


\section{Between Memory and Imagination: Writing Towards the Truth of the Self}

The first three parts of the novel are recounted in the third person narrative style which, although combining various techniques and poetics - classical realism, hints of modernism in the stream of consciousness presentation and impressionism (part I), reduced naturalism (part II), etc., never questions the omniscient position of the authorial narrator in building of a realistic story of personal histories set in a firm social and national context. We read of one crucial hot summer day in the protagonists' lives, in 1939, when thirteen-year old Briony Tallis, an inexperienced girl with too vivid imagination, wrongly accused Robbie, her sister's Cecilia's boyfriend and a son of the family's loyal employee, of raping their young cousin Lola. Briony is masterfully depicted as a self-absorbed teenager (McEwan's psychological penetration into the character of the "border-line" age between childhood and maturity has proved its depth and clinical accuracy once again), slightly spoiled, obsessed with order and secrets (although empty, ${ }^{3}$ non-existent, invented), with strong literary aspirations and equally strong awareness of the class system. Out of the dark and indistinguishable comingling of all these characteristics, her motive to make the fatal accusation is reinforced by her egotistical need to create a tale, a plausible arrangement of things in which she would be a "savior", a knowing heroine and a judge. Robbie is sent to prison and afterwards to serve in the WWII, which is presented with disturbingly detailed naturalism in Part II that narrates his and other wounded soldiers' sufferings during the retreat at Dunkirk. In the third part of the novel, which centers on Briony's excruciatingly hard work as a nurse in the war hospital and her gradual realization of the terrible mistake that she had made ruining two lives - Robbie's and her sister's - we learn that the lovers are, after all, reunited: she pays a long planned visit to Cecilia, who, although not ready to forgive her (yet), decides to accept her offer to set the things right legally and officially change her previous statement. However, the last section of the novel, titled "London, 1999" - the same words which, in a form of signature or quite unexpected post-scriptum, oddly end the previous section - breaks the mimetic illusion and subverts the story's realist assumption, as we find out that it has all along been Briony's narrative, actually, one of many:

It is only in this last version that my lovers end well, standing side by side on a South London pavement as I walk away. All the preceding drafts were pitiless. But now I can no longer think what purpose would be served if, say, I tried to persuade my reader, by direct or indirect means, that Robbie Turner died of septicaemia at Bray Dunes on 1 June 1940, or that

3 Peter Mathews makes this point several times in his article: cf. Mathews, "The impression of a deeper darkness: Ian McEwan's Atonement." 
Cecilia was killed in September of the same year by the bomb that destroyed Balham Underground station. [...] I know there's always a certain kind of reader who will be compelled to ask. But what really happened? The answer is simple: the lovers survive and flourish. As long as there is a single copy, a solitary typescript of my final draft, then my spontaneous, fortuitous sister and her medical prince survive to love. (McEwan, Atonement, 370-71, emphasis in original)

In fiction, therefore, in her storytelling, now 77-year old Briony, a renowned writer, tries to amend what she failed to do in the empirical life: to change absurdly painful histories, to restore what she destroyed, to unite the unjustly separated lovers. It is important to mention that an excess of imagination, the fabulation of facts and experience, was what separated them in the first place: Briony's accusation of Robbie and her will to believe (and make everyone else believe) that he was the rapist was to a large extent caused by her need to have a pattern, a symmetry in a story of good and bad characters, heroes and villains, as her perception was shaped by literature from the earliest stages of her development (by black-and-white stories at first, morality plays, etc., much like the one she tries to stage to welcome her brother, The Trials of Arabella, ordering the roles and behaviors of her little "actors"). Now, somewhat ironically and more significantly, it is again through words and imagination, through new type of knowledge and extended emotional intelligence, through memory and creation of yet another narrative, that she tries to correct her mistakes and reach an atonement, or at least a possibility of atonement. Moreover, we deduce that her entire life has been determined and shaped by that mistake and the attempt to correct it: her existence as a character and an author of this novel has taken form of the need to atone: to realize at-one-meant ideal of fusing reality and fiction, past and present. It is both the authorial drive and a deep anthropological claim, common trait of humanity, which urges Briony to try to connect storytelling with the structure of life - to make a unity, a meaningful whole of the fragmented pieces. The question of authorial position arises with an acute awareness concerning its limitations:

The problem these fifty-nine years has been this: how can a novelist achieve atonement when, with her absolute power of deciding outcomes, she is also God? There is no one, no entity or higher form that she can appeal to, or be reconciled with, or that can forgive her. There is nothing outside her. In her imagination she has set the limits and the terms. No atonement for God, or novelists, even if they are atheists. It was always an impossible task, and that was precisely the point. The attempt was all. (McEwan, Atonement, 371) 
Teleologically, the problem Briony is facing is the core existential and ontological problem of all secular confessions: the problem of authority. Justifiably classifying Atonement as an example of confessional fiction, or fictional confession, D'Hoker notices the determining difference between religious and secular, or literary, confessional discourse: that of an institutionalized authority empowered to give forgiveness. ${ }^{4}$ Whereas religious confessions by definition always presuppose one, the performative nature of the act itself being closely connected to the belief in the certainty of its telos, secular confessions are marked by uncertain authority and oriented towards the process itself, rather that its outcome. In addition to this, another important distinguishing feature is the fact that, unlike religious confessions, which are focused on the plausible goal of obtaining absolution, fictional confessions are rather centered on a quest for truth: "an intensely personal, interior truth: a, or rather the, truth of the self. True facts do not matter as much as authenticity: the true self that lies behind these facts" (D'hoker 32, emphasis in original) Briony's fifty-nine years long process of re-writing the history of two lovers, which she tragically modified in the first place, was also - and inevitably - the process of discovering and re-writing the self, for her confession comes very close to autobiography in its form, its intention and its desired goal. The truth of the self is something which both a confessant and an autobiographer are turned to in their creative quests, and for the author it is always inextricably linked to the very act of telling/writing, as it is through the telling/writing that it emerges. It is in the process of imaginative recreation of reality, her own as well as others', which she herself initially wrongly created by her act of misinterpretation of the facts, that Briony's narrative becomes actually a story of herself and her development as a character and as an author.

The strong association between the truth of subjectivity, rather than a subjective truth, on the one hand and authority and authorship on the other, is inevitably intertwined with the notion of historicity of self (and of the truth of the self), as well as with the recognition of its fictionality. Atonement is entirely imbued with various notions of history, historicity and memory. Apart from being structured as a revision of and an homage to the English literary history - and memory of it - through its intertextuality, multiple narrative styles and interest and affinity that all three protagonists share when it comes to literature, it also encompasses a national and European history, which intertwines with private histories, as well as a social history (British class system, pre-war and post-war transformations of social milieu), etc. Also, the significance of spatial memory is addressed in the last part: Briony walks past the houses where

4 D'hoker uses the labels "confessional fiction" and "fictional confession" alternately to describe the same type of narrative. Cf. Elke D'hoker, "Confession and Atonement in Contemporary Fiction: J. M. Coetzee, John Banville, and Ian McEwan." 
various members of her family and friends once lived, noticing that " $[B]$ eyond a certain age, a journey across the city becomes uncomfortably reflective. The addresses of the dead pile up" (McEwan, Atonement, 355). At last, but not the least, memory plays a crucial structural and thematic role in a novel whose protagonist and narrator is diagnosed with vascular dementia, that is, a gradual, inevitable and complete loss of memory that defines her as an author and that defines us all as human beings. Along with the remembrance of people, events and the empirical past in general, as a temporal succession of various lives and realities, the importance of literary memory - at both fictional and metafictional level, i.e. in both Briony's and McEwan's case - is reflected in the pluralism of narrative techniques and different poetics that marked the development of the British novel through time. ${ }^{5}$ In the allusiveness and intertextuality of Atonement, in the layering of different prose styles and modes of writing which both authors, Ian McEwan and Briony Tallis, employ, it becomes clear that the concepts of authorship and authority largely depend on a particular style the author chooses at a time, since it is the narrative perspective and the narrative voice that determine and construct these concepts and what is produced by them. Furthermore, the ethical implications of a chosen style, as well as the ethical implications of every authorial activity, proceed from the recognition that subjectivity is always constructed (being deconstructed, and then reconstructed) over time, and through time, as much as through a narrative: through various ways of fictionalising one's own history as well as others'. Every narrated history turns into a story, a fiction, in the very process of being told (let alone written), just as every storytelling re-imagines and re-creates a history: a possible reality, as it might have happened, no less real than the one which did happen and which frames it. We learn that Briony's final authority is not unfounded: it is based upon her history and her development as an author, upon her many different attempts to write the novel about Cecilia and Robbie, which eventually ends in a self-reflexive version that foregrounds her own authorial and self-constructed position, telling at same time the poignant story of the two lovers. And this is precisely the point where the realistic and ethical significance of metafiction steps in and where the self-referential narrative becomes highly referential, with humanistic appeal. As B. Finney puts it, "when novelists force us to understand the constructed nature of their characters, they invite us simultaneously to reflect on the way subjectivity is similarly constructed in the non-fictional world we inhabit" (76). Understanding the fictional nature of what we call "the real life" and comprehending the fictional nature of every process of remembering and recounting "the real history" leads, by the logic of analogous reversal, to acknowledging the reality of invention, the truth of fabulation,

5 Pilar Hidalgo enumerates various aspects of literary memory and novelistic history in Atonement. Cf. Pilar Hidalgo, "Memory and Storytelling in Ian McEwan's Atonement." 
and, hopefully, a healing power of imagination to restore, in this fluctuation of facts-fiction boundaries, what was broken in the non-fictional part of history.

Ars memoriae, even according to a most sober scientific definition, is closely related to invention and creative construction:

The art of memory (Latin: ars memoriae) is any of a number of loosely associated mnemonic principles and techniques used to organize memory impressions, improve recall, and assist in the combination and "invention" of ideas. (Wikipedia, my emphasis)

In Briony's case, perhaps in every writer's case, the relationship is more than obvious: the combination of memory and imagination is something that directs and redirects her writing, her confession, her novel and its numerous drafts, her quest and dream of atonement. Both memory and imagination are being extended over time to include acceptance and compassion, revisions of attitudes and narrative styles, as well as multiplication of perspectives and standpoints. "The attempt was all," she says, recognising and accepting that it is in the process only that the goal can be reached, or at least glimpsed at: the goal of bringing life and text as close to one another as possible, the goal of connecting history and story, and, ultimately, the authorial and the experiential self in a way that reshapes and amplifies them both.

\section{Literary Self-invention as an "Upward Fall"}

In a world where "There is no one, no entity or higher form that she can appeal to,", where "[t]here is nothing outside her," as she says, Briony's authority starts to emerge from her honesty and the authenticity of recognizing herself, as painful as it may be, "between self-exculpation and self-laceration" (Head 166), as a fallible character and as a fallible author. As D'Hoker pointed out in his article on confessional fictions, recognising the Self and - very importantly - accepting the Self is one possible way out of the confessional labyrinth. ${ }^{6}$ In the course of many versions of her narrative about Cecilia, Robie, her family and her crime, which is also and inevitably a self-narration, Briony Tallis accepts her own illusions and mistakes, without denial or embellishments, she embraces her own guilt and repentance, and consequently, possibly, opens up a hope for, if not forgiveness, than a growth. McEwan provided a simple yet quite revealing comment about the psychological and moral implications of the storytelling, which is lifelong in this case: "I wanted to play with the notion of storytelling

$6 \mathrm{It}$ is a labyrinth-like process because, as much as it reveals the true Self, confessional (autobiographical) narrative can also paradoxically mask the Self, in the very process of always new narrative strategies that entail also appearance of new aspects of the Self. Cf. D'Hoker, pp. 34-35. 
as a form of self-justification, of how much courage is involved in telling the truth to oneself" (in Head 163). It is a sort of inner authority, when there is no external (at least not perceived to be), that comes out of the "truth of the self" and out of self-acceptance or, as D'Hoker concludes: "Being created in the slow process of writing, the truth of confession seems to involve an authoritative acknowledgement of this truth as mine" (42, emphasis in the original).

Construction of the Self through narration, especially through a confessional narrative, leads not only to the acknowledgement of its historicity and its always partly fictional, and therefore unstable, changeable, character, but also opens up an indefinite space for the expansion of the Self. Self-recognition and self-acceptance contain an enormous potential for qualitative enlargement: in psychological, ethical and existential terms, as the modern psychology has continually stressed out. The concept of the sublimation of the self, offered by Ludwig Binswanger, a Swiss psychiatrist and a pioneer in existential psychology, can serve as a very useful tool for reflecting on the connection between the Self, writing/storytelling and ethical potential of fiction. In the context of the novel such as Atonement, with its highly self-conscious meditation upon the somewhat morally dubious authorial role ${ }^{7}$ and the artist's responsibility towards life, Binswanger's claims that as human beings "(we are) free to design (ourselves) toward the most different potentialities of being" and that our existence, particularly through dedication to a creative authorial activity, "transcends the being" (May 191-213), are profoundly consonant with McEwan's extended interest in narrative ethics and ethical implications of story-telling and story-reading, which are always imaginative projections into another, but also, self-reflexively, into ourselves. In his summery of Binswanger's main attitudes, Paul De Man provides valuable insights into the role literature can have in the extension, transcendence and re-definition of the self and being. The author's subjectivity, but also the reader's at another level, is positioning itself only in relation towards the constitutive and formative categories of being, expressed through fiction, trying to resist the concerns and limits imposed by the empirical being and the empirical, external world. Focusing on Binswanger essay on Ibsen entitled "Hendrik Ibsen and the Problem of the Developing of the Self in art," De Man says that "[f]or Binswanger, literary enterprise can never be separated from the project of self-realisation" (40), while his reflection upon the writer's renunciation of the self he inherited and his relinquishing of the "particular circumstances that defined his initial situation in the world: family, place of birth, psychological and sociological conditions" (39) unmistakably reminds of Briony's self-sacrifice and renunciation of her familiar contexts and her original identity in the pursuit of literary enterprise that, for her, equals atonement. This

7 For the discussion of moral ambivalence contained in Briony's and, inherently, any modern novelist's authorial position, see: Head pp. 156-174. 
type of self-realisation necessarily entails an expansion, an extension of the Self, which, as De Man reminds us, Binswanger conceived as a vertical rather than horizontal development in his phenomenological and existential psychology. It is a vertical movement, a quest upward (or downward, if depths of the self are the point of reference), a sublimation, which is potentially endless process. Thus, Briony's endless rewriting of her atonement in various narrative styles and in various voices and perspectives, her lifelong literary project, is a sort of upward fall, to rephrase Binswanger's idea of the ontological fall of the poetical consciousness, during which she falls into other existences over time, allowing them their own voices and perspectives.

"It was always an impossible task, and that was precisely the point," writes Briony Tallis in the final chapter, which again echoes Branswinger's notion that the work of art is directed towards "an unreachable goal, and its partial success takes on the form of 'a renunciation at the very moment when it comes into being'" (De Man 43). Briony's renunciation, expressed also in her refusal to give herself forgiveness in the world of her novel, is profoundly intertwined with the breaking of the limits of her ego, with pushing forward of the boundaries of her known self, with reinventing the self. Her writing serves as a process of authentication of the enlarged self that is lifted above its initial circumstances. However, the mental and creative transformation of Briony, her change and growth both as a character and an author, is enacted also as a reduction in a certain sense, as an ontological contraction, since at the end of the novel she denies herself a superior ontological status, becoming one of the characters, one of her own inventions, going off to sleep and leaving the text somewhat open. It is through this sort of final imaginative leap, which is self-accepting and self-denying at the same time, that Briony Tallis recreates herself in a poetically and ethically upward direction, at the same time extending and lifting to another level the ethical and dialogical potential of the metafictional narrative itself.

The ethical and humanistic appeal of Briony's as well as McEwan's selfreflexive metafiction consists precisely in its ability to show the movability and flexibility of boundaries in the realisation of the reality of others, as Briony herself once thought. Imagining other's reality through constituting a narrative, a fiction which shapes not only their history - the history of others - but, as we can see, the history of the author's Self, has a fundamental ethical dimension and important social implication. In his moving response to the 9/11 terrorist attack, McEwan wrote, among other things, about the crime as a failure of imagination:

If the hijackers had been able to imagine themselves into the thoughts and feelings of the passengers, they would have been unable to proceed. It is hard to be cruel once you permit yourself to enter the mind of your 
victim. Imagining what it is like to be someone other than yourself is at the core of our humanity. It is the essence of compassion, and it is the beginning of morality. ("Only love and then oblivion. Love was all they had to set against their murderers", The Gardian)

All the richness of McEwan's narrative ethics is reflected precisely in this notion: Atonement is both a fictional and a metafictional demonstration of the importance of imaginative projection "into the other people's shoes". Fictionally, it dramatizes Briony's crime, guilt, punishment and the need to atone: her tragic mistake was first caused by an excess of imagination, but it was a narcissistic imagination which led to misreading of reality, whereas her painful and restorative upward fall lead her to yet another order of imaginative capacity and that is empathetic imagination, which meant honest emotional engagement with the world of others. Metafictionally, the novel reflects on the ambivalent authorial role and the responsibilities it entails, on the potential risks and healing powers of the imagined stories, on the ways in which we construct them and - more significantly - the ways in which they construct us and our reality. The emotional and moral responses to Briony as a character, as well as to other characters and their individual and shared fictional destinies, along with selfreflexive contemplation of Briony as an author whose psychology and ontology largely depend on her own narrative, stir reader to engage in the complex social and ethical awareness this novel generates. In that light, the metafictional ending, rather than destabilising realist reading contract, actually reinforces the mimetic claims of the text and its effective communication with the readers or, as Peter Mathews said:

the novel's structural twist is meant to engage the reader in a reversal of perspective. The reader's judgment of Briony suddenly becomes preemptive, insofar as we have shown ourselves to be hasty in our morality and our willingness to judge (157, emphasis in the original).

The appreciation of the complexity of others, the value of restraining from judgement, the realisation of the reality of other people's feelings, experiences and personal histories are the crucial messages Briony Tallis poignantly learned and relearned through an imaginative extension of empathy, which was exercised through decades of narration - a storytelling that was the starting point and also the final product of empathy. Its further extension additionally encompasses the readers in the self-conscious coda of the novel, since Briony's creative authority eventually deconstructs and surpasses itself, demonstrating the restorative, healing and purposeful potential of fiction to amplify experience at many levels. 
Arguing in favour of the view that Ian McEwan belongs to that not so numerous group of the contemporary novelist whose interest in the narrative ethics always, in its final analysis, has prevalence over the postmodernist poetics, O'Hara concludes that metafictional style of McEwan's novels is "less a parody of realist techniques than a self-conscious working-through of realist aims in light of postmodernity" (O'Hara). The realist and mimetic preoccupations are evident not only in the sense of the lived, socially and psychologically vibrant experience his text invokes, but also in the powerful invitation to the readers to identify with the characters, to invest sympathy and empathy while recognizing not only the characters', but also their own, our own, constructed identities, which can, consequently, be reconstructed and meaningfully enlarged. McEwan's Atonement, therefore, despite or precisely because of its postmodernist strategies, reasserts the ancient role of storytelling as an expansion of the self in the direction of an ethical and emotional relation towards the other.

\section{Works Cited:}

D’hoker, Elke. "Confession and Atonement in Contemporary Fiction: J. M. Coetzee, John Banville, and Ian McEwan." Critique: Studies in Contemporary Fiction, 48.1 (2006): pp. 31-43.

De Man, Paul. "Ludwig Binswanger and the Sublimation of the Self", in: Blindness and Insight: Essays in the Rhetoric of Contemporary Criticism. New York: Oxford University Press, 1971. 36-50.

Finney, Brian. "Briony's Stand Against Oblivion: The Making of Fiction in Ian McEwan's Atonement." Journal of Modern Literature 27.3 (2004): 68-82.

Head, Dominic. Ian McEwan. Manchester University Press, 2007.

Hidalgo, Pilar. "Memory and Storytelling in Ian McEwan's Atonement." Critique 46.2 (2005): 82-91.

https://en.wikipedia.org/wiki/Art_of_memory, accessed at: 2018-08-19

Lodge, David. The Novelist at the Crossroads: And Other Essays on Fiction and Criticism. Cornell University Press, 1971.

Mathews, Peter. "The impression of a deeper darkness: lan McEwan's Atonement." English Studies in Canada, 32.1 (2006): 147-160.

May, Reese (ed.), Angel, Ernest (ed.), Ellenberger, Henri F. (ed.). Existence: $A$ New Dimension in Psychiatry and Psychology. Northvale NJ: Jason Aronson Inc. Publishers, 1994.

McEwan, lan. "Only love and then oblivion. Love was all they had to set against their murderers." The Guardian. 15 September 2001. https://www.the- 
guardian.com/world/2001/sep/15/september11.politicsphilosophyandsociety2, accessed at 2019-02-27.

McEwan, Ian. Atonement. London: Cape, 2001.

O'Hara, David K. “Mimesis and the Imaginable Other: Metafictional Narrative Ethics in the Novels of Ian McEwan" http://www.ianmcewan.com/resources/docs/OHara-Excerpt.pdf, 2018-08-22.

\section{NOVO ZAMIŠLJANJE ISTORIJA, NOVO STVARANJE SOPSTVA U MAKJUANOVOM ISKUPLJENJU}

Opravdano svrstan među primjere postmodernog realizma, ili takozvane "rekonstruktivne metafikcije" (O'Hara), Makjuanov popularni i kritički visoko ocijenjeni roman Iskupljenje (2001) u cjelosti potvrđuje često navodjenu izjavu autora da "zamišljajući kako je to biti neko drugi stiže se do srži naše humanosti". Fokusirajući se uglavnom na metafikcijski završetak romana, koji, poput nekog neobičnog post-skriptuma, donosi svojevrstan tematski, strukturni i ontološki zaokret, preusmjeravajući čitavu priču, u ovom radu se istražuju ograničenja i potencijali kreativne imaginacije, kao i njena moć da iznova generiše, ispravlja i smisleno proširuje lične istorije, čime se ukazuje na suštinsku etičku dimenziju savremene samosvjesne proze. Fenomenološka veza između ars memorije, imaginacije, pisanja (iznova) i Sopstva je ovdje sagledana kroz osnovnu pretpostavku egzistencijalne psihologije prema kojoj je subjekat sposoban da transcendira sebe, iznova stvarajući sebe kroz naraciju o sebi i drugima. Analizirajući Brajoni Talis i kao junakinju i kao autorku unutar romana, u njenom pripovijedanju o sopstvenoj i tudjim istorijama, ovaj rad će se baviti etičkim mogućnostima autoreferencijalne proze u povezivanju subjekta sa svijetom, čime se $u$ isti mah preispituju i granice prošlosti, sadašnjosti i ideje o realnosti.

Ključne riječi: postmoderni realizam, zamišljanje iznova, kazivanje, Sopstvo, prihvatanje, uvećanje, narativna etika. 